\title{
THE INFLUENCE OF THE UNITED STATES ARMY ON THE DEVELOPMENT OF THE INDONESIAN ARMY (1954-1964)*
}

\author{
Bryan Evans III
}

\section{Introduction}

This article will focus on the American influence, specifically that of the US Army, on the development of the Indonesian Army (TNI, Tentara Nasional Indonesia) between 1954 and 1964, a critical decade in Indonesia's political history. The success of the American military aid program in Indonesia during this period ultimately hinged on the training provided to the Indonesian Army's officer corps by the US Army . In order to gain an understanding of the importance of this effort, I will first look at how the Indonesian government, and specifically the Army, were seen from both Washington and from the American Embassy in Jakarta. I will then portray the personalities and attitudes of the main American players and their influence. I will examine the programs through which military aid to Indonesia was channeled, and, finally, the effect all these factors had on the Indonesian Army.

\section{Overview}

During the mid-1950s, the Eisenhower Administration's relations with Indonesia were strained by the powerful position of the Indonesian Communist Party (PKI) in

\footnotetext{
"This is a revised excerpt from an MA thesis of the same title, submitted to Corncll's Department of Asian Studies for degree completion in May 1988. The author is greatly indebted to Professor Frederick Bunnell, presently on the faculty of Vassar College, for permission to use his valuable and extensive notes in this article. Dr. Bunnell's notes, as well as the Cornell Modern Indonesia Project's (CMIP) Current Data, are on file at Cornell University.
} 
Jakarta's politics and by the poor personal relationship between Sukarno and Washington. ${ }^{1}$

With the PRRI/Permesta rebellion, Indonesia became a major focus of Washington's attention. While both the TNI and the American Embassy in Jakarta perceived the rebellion as being based essentially on regional and internal military disaffection, ${ }^{2}$ the CIA painted the rebels as anti-Communist and nearly all other groups in Indonesia as Communist or potentially Communist. To consider policy alternatives in the fall of 1957 , the administration in Washington established an Ad Hoc Inter-Agency Committee, ${ }^{3}$ which developed three major proposals for preventing the possibility of a Communist takeover in Indonesia: first, to strengthen and encourage the anti-Communist forces in the Outer Islands, so that they could "affect favorably the situation on Java and provide a rallying point" if the Communists did take over there. Second, should the situation in Java continue to deteriorate, to move more quickly on the first recommendation. Third, to use whatever leverage was available, "or might be built-up by the anti-Communist forces in the outer islands, to stimulate into action the non- and anti-Communist forces in Java. ${ }^{4}$

Washington's clandestine support of PRRI/Permesta rebels in 1958 exacerbated the tensions between the US and Indonesia, and the situation was not alleviated by Sukarno's declaration of Guided Democracy. With its implementation in 1959, the Eisenhower Administration came to view the Indonesian government as increasingly pro-Communist. The abolition of parliamentary democracy, and the imposition of rule by Presidential Decree led to a situation in Indonesia where politics revolved around three centers, i.e., Sukarno, the PKI, and the Army. ${ }^{5}$ This increase in PKI influence at the center of power was to become the focal point for US policy in Indonesia.

During the Kennedy, and the early Johnson Administrations, the period 1960-1965, four major issues dominated relations between Washington and Jakarta: settlement of the West Irian dispute; the Confrontation between Indonesia and Malaysia; Sukarno himself; and the rise of the PKI.

Throughout this difficult decade in US-Indonesian relations, the embassy, under both Ambassadors John Allison and Howard Jones more often took a more moderate view of internal political developments than either the CIA or the State Department. ${ }^{6}$

\footnotetext{
1Though Sukarno made a visit to Washington in 1956, and repeatedly extended invitations to Eisenhower to visit Indonesia (five times), he was just as repeatedly put off. According to former Ambassador Allison, Eisenhower saw Sukarno as a Communist and a playboy, and Eisenhower was not going to do anything to build up Sukarno's prestige among the Indonesian people. John M. Allison, Ambassador from the Prairie or Allison Wonderland (Boston: Houghton Mifflin Company, 1973), pp. 311-14.

2See Ruth McVey, "The Post-Revolutionary Transformation of the Indonesian Army," Parts 1 \& 2, Indonesia 11 (April 1971): 131-76; and 13 (April 1972): 147-81, respectively.

${ }^{3}$ See Allison, Ambassador from the Prairie, pp. 313-14; Allison does not specify the date this committee was formed, but US government documents place it in September 1957.

${ }^{4}$ Allison, Ambassador from the Prairie, pp. 313-14.

${ }^{5}$ The definitive study on this period is, of course, Herbert Feith, The Decline of Constitutional Democracy in Indonesia.(Ithaca: Cornell University Press, 1962).

${ }^{6}$ Allison, Ambassador from the Prairie, pp. 307-15. Though Ambassador Allison was only assigned to Indonesia for eleven months (1957-1958), he developed an understanding and appreciation of the Indonesian people and their desires that was missing in Washington. His particularly frustrating Indonesian experience is described on pages $293-344$, but the above referenced pages detail his specific frustrations with the Dulles brothers, the CIA Station Chief, and overall Washington policy.
} 


\section{The Personalities}

Howard Palfrey Jones assumed the ambassadorship in 1958 at a time when Indonesia was in the middle of the PRRI/Permesta Rebellion. This was not his first tour in Indonesia. From 1954-1956 he had served as head of the economic aid mission there, and he had then developed a great affection for the country and her peoples. While he agreed with and supported the goals of Washington's policy toward Indonesia, i.e., an Indonesia free and non-Communist, Ambassador Jones did not endorse Washington's tactics, ${ }^{7}$ for, although the US publicly espoused a policy of neutrality in the rebellion, it was covertly supplying military aid to the rebels. Jones advocated a serious about-face for American policy, advising Washington that it was the Indonesian Army that was likely to determine Indonesia's future, and if it remained anti-Communist it could be counted on to prevent any Communist takeover. ${ }^{8}$ It was only in the aftermath of the shooting down and capture of Allen Pope, an American pilot flying for the rebels that his advice had some effect and there was a change in US policy. ${ }^{9}$

Even after this change, President Sukarno continued to be a problem for American policy-makers, and Ambassador Jones' difficulty lay in persuading Washington that it was possible both to work with Sukarno and to maintain the anti-Communist posture of the Indonesian Army. ${ }^{10}$

Perhaps the most contentious issue for Jones and the embassy was the "Confrontation" or "Crush Malaysia" campaign which Sukarno initially launched on February 13, 1963. Opposing the formation of the Malaysian Federation as a British imperialist ploy, the Indonesian president, with the support of the PKI and some elements of the military, soon began sporadic armed operations against Malaysia principally along its border with Indonesian Kalimantan. The TNI was split over the issue: some officers supported the campaign because they feared the new federation might be drawn into the Chinese Communist sphere; ${ }^{11}$ many senior officers saw confrontation as a justification for maintaining a large army; but others worried that the operations against Malaysia would disperse army strength from politically crucial Java.

Jones continued to argue that the Indonesian Army and the United States were in basic agreement on the requirements for maintaining a "free and independent" Indonesia and that the TNI could be counted on to restrain Sukarno from going to

\footnotetext{
${ }^{7}$ Howard Palfrey Jones, Indonesia: The Possible Dream (New York: Harcourt Brace Jovanovich, 1971), p. 121.

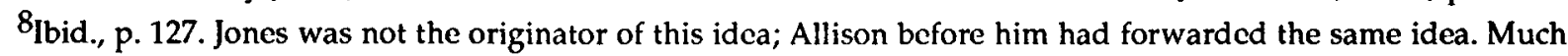
later during Jones' tenure, Guy Pauker formulated a similar hypothesis; sec Guy Pauker, "The Role of the Military in Indonesia," in The Role of the Military in Underdeveloped Countries, ed. John J. Johnson (Princeton: Princeton University Press, 1962), pp. 185-230.

${ }^{9}$ Jones, Possible Dream, pp. 143-46. Though Jones docs not actually state that this was the effect of the Pope Incident, it is very evident from these pages that the dichotomy in US policy forced Washington heed Jones' suggestions. Apparently, the policy change had occurred about 4-5 days before the incident (Conversation with Professor George Kahin, April 1, 1988). In the incident, the Indonesians downed Pope's unmarked aircraft, which had been supporting the rebels. Pope himsclf was carrying a complete set of identification papers, including membership at the Clark Air Base Officers Club. Col. Benson appears to have been largely responsible for helping to shift the attitude of the Pentagon on Indonesia. Conversations with Col. Benson.

${ }^{10}$ At the height of the West Irian dispute he advocated supplying the Army with arms aid, to underline US confidence in Nasution and the Army. But, Nasution was turned down during his October 1960 arms-buying visit to Washington. See Jones, Possible Dream., p. 189.

${ }^{11}$ Harold Crouch, The Army and Politics in Indonesia (Ithaca: Corncll University Press, 1978), p. 59.
} 
extremes. ${ }^{12} \mathrm{He}$ contended that, despite the Indonesian president's actions, it was unwise to abandon such strong anti-Communist elements as the Army and the paramilitary forces of the Mobile Brigade (Mobrig). The maintenance of US assistance to these groups would fortify them for the inevitable showdown with the PKI. ${ }^{13}$ Jones' support of the Army went far deeper than he admits to in his autobiography, for in early March 1964, in a conversation with General Nasution, he cautioned him regarding the impact on Indonesia of Confrontation and the rise of the PKI, and inquired about the possibilities for a coup against Sukarno, hinting at US support of such a move. ${ }^{14}$

Throughout 1964 and 1965, and especially after Sukarno's "Go to hell with your aid!" Independence Day speech on August 17, 1964, Jones had an uphill battle to maintain even reduced levels of US aid to Indonesia. ${ }^{15}$ However, he was not alone in his efforts to win Washington's support, for he had a very valuable ally in the person of his military attaché, Colonel George Benson.

Colonel Benson first came to Indonesia from October 1956 to July 1959 as an assistant military attaché. During the first of these years the two senior officers with whom he worked were relieved, and from 1957 until mid to late 1958, Colonel (then Major) Benson was the only US Army officer in Indonesia. This point cannot be over-emphasized, for it was during these months that the close ties between Benson and the Indonesian military leadership were developed. ${ }^{16}$

In many ways Benson was a typical US Army officer. A graduate of the US Military Academy near the top of his class, he was assigned for combat duty in Korea and was one of his class's first battalion commanders. In 1954-1955, he attended the Command and General Staff College (CGSC) at Fort Leavenworth, where one of his classmates was Candra Hasan. ${ }^{17}$ He also briefly met then Colonel Ahmad Yani, who was preparing to enter the CGSC class of 1955-1956.18 After completion of CGSC, Benson then took language training and the attaché's course before beginning his assignment in Indonesia.

This first assignment was to be the most crucial one from the standpoint of both the Indonesian military and Colonel Benson. The close ties that Benson developed with the leadership-Generals Nasution, Yani, Mokoginta, and Kartakusumah among otherswere to shape not only his career, but the development of the TNI. The trust between them was cemented during the PRRI/Permesta Rebellion. Benson did not agree with the CIA's position on the rebellion, and his lack of knowledge about the Agency's activities

12 Jones, Possible Dream, p. 312.

13 Ibid., pp. 324-25.

${ }^{14}$ Declassified Documents Reference Service (Hereafter referred to as DDRS), followed by (brackets) with the year group of the document in the (brackets). DDRS(75) 117C; Cable from Jones to the Secretary of State (March 6, 1964). Jones came to three conclusions from his mecting, but the last point is most interesting; he stated: "He (Nasution) avoided like the plague any discussion of possible military takeover, even though this hovered in the air throughout talk, and at no time did he pick up obvious hints of US support in time of crisis." ${ }^{15}$ Jones, Possible Dream, pp. 324-25; p. 345, and pp. 363-64.

${ }^{16}$ Correspondence and conversation with Colonel Gcorge Benson, January 11, 1988 and February 4-5, 1988, respectively.

${ }^{17}$ Candra Hasan had been an ally of Nasution's, trying to negotiate with Warouw after his assumption of power in the wake of the "17 October Affair." For a short period of time he headed SUAD I (Intelligence), but was fired and replaced by Sukendro on December 13,1956. He disappeared from sight after this and did not surface again until the 1980s in connection with the retired officers' protests against the Suharto regime.

${ }^{18}$ Correspondence and conversation with Col. Benson, January 11 and February 4-5, 1988. 
during the strife, as well as his support to Washington of the position of the Indonesian General Staff, created an enduring bond between him and senior officers of the TNI. ${ }^{19}$

Benson's achievements did not go unnoticed in Washington, for at that time the US Army Chief of Staff was General Maxwell Taylor. General Taylor had been viewing the developments in Indonesia with some interest, noting that the military attachés reports conflicted with those of the CIA. Benson was telling the Pentagon that the rebellion was not one of non-Communist versus Communist forces, but rather a split within the nonCommunist faction in Indonesia. ${ }^{20}$ This position was rendered more plausible by the fact that the central government's military leaders were all US trained, while none of the rebels had any US training. ${ }^{21}$ The crucial turning point came on the issue of purchasing weapons. ${ }^{22}$ When the Pentagon turned down his request for arms, Nasution asked Benson to see if this also meant that the training of Indonesian officers in the US was to be halted. General Taylor's reply was that the US Army would train every officer that the Indonesian Army made available. General Taylor was so impressed by Major Benson's performance during the rebellion that he personally upgraded the Army Commendation Medal awarded to him to a Legion of Merit; quite an honor for a Major, as the Legion is generally reserved for officers with the rank of Lieutenant Colonel or higher. ${ }^{23}$

At the request of Generals Nasution and Yani, Benson returned to serve in Indonesia from August 1962 to July 1965 as Special Assistant to the Ambassador for Civic Action. ${ }^{24}$ During this period the Indonesian Army was beginning to be openly confronted by the PKI in the villages (through the unilateral action campaign). ${ }^{25}$ Because of the Indonesian Army leadership's confidence in him, Benson, then a Lieutenant Colonel, was given almost autonomous control over the conduct of the civic action program in Indonesia. 26 Ambassador Jones got along very well with Benson, and fully supported the program as

${ }^{19}$ Benson related one example of his cooperation with the TNI: In planning for the Sumatra operations the TNI General Staff lacked the necessary maps of Sumatra. General Yani telephoned Benson asking him if the embassy had the required maps, and if so could he please get them now? Although this was around midnight, according to Benson, he took the maps to Yani and the staff, who were working out their plans in a private home. Benson said he stayed for several hours listening to the conversation and then departed. Ibid.

20 Ibid.; it also did not hurt that Ambassador Jones was supporting and promoting the same position through State Department channels. See Jones, Possible Dream, pp. 124-25.

${ }^{21}$ Of the rebel leaders, Alex Kawilarang, Lubis, Simbolon, Husein were in Sumatra, while Warouw and Sumual were in Sulawesi. None of these men had any US training. On the other hand, the GHQ consisted of Yani, Rachmat Kartakusumah, Achmad Mokoginta, and Candra Hasan among others, who were all US trained. Current Military Data for Indonesia, Bunnell Notes, all of which are on file with the Cornell Modern Indonesia Project, as well as a listing of Indonesian officers who attended the US Army's Command and General Staff College.

${ }^{22}$ Nasution had gone to Washington in 1960 to request a large arms purchase, but he was turned down and ultimately was forced to get them from the Russians.

23 Benson, correspondence January 11, 1988.

${ }^{24}$ Benson stated that, on this second tour, he was requested by Generals Nasution and Yani, and, on his third tour by Ambassador Galbraith.

25 Aksi Sepihak, or unilateral action, refers to the period 1963-1965 when the PKI's efforts at instituting the 1960 Agrarian Reform Law moved into the arena of physical confrontation with the landowners and ultimately the Army. For more information on this issue, sce Rex Mortimer, The Indonesian Communist Party and Land Reform 1959-1965 (Clayton, Victoria: Monash University Papers on Southeast Asia no.1, 1972).

${ }^{26}$ Civic Action Briefing, given by Col. Benson, provided by the CMIP, courtesy Professor Ben Anderson. 
the only remaining tool available to the United States to help support the Army against the PKI. ${ }^{27}$

During the early 1960s, the new Kennedy Administration brought to office in Washington a group of bureaucrats and politicians who agreed with the goals of Jones and Benson. Perhaps the most important players, at least from the point of view of Ambassador Jones, were the new faces in the State Department, especially the Far East (FE) Bureau. Within the State Department, the new Assistant Secretary for the Far East, Averell Harriman, enthusiastically supported the idea of an Indonesian Military Assistance Program (MAP). Harriman also hand-picked the President's new National Security Council Assistant for the Far East, Michael Forrestal. In the FE bureau there were Robert Lindquist and James Bell, both strong supporters of Ambassador Jones. These men were all linked with the Pentagon through James Rafferty, who was the Indonesian desk officer in the Department of Defense's International Security Agency (ISA). His boss in ISA was William Bundy, brother of the National Security Adviser, McGeorge Bundy. 28

The last link in the Washington group was General Maxwell Taylor, who was at one time the Chief of Staff of the US Army (CSA), and later Chairman of the Joint Chiefs of Staff (CJCS). While he was serving in those positions, he not only had the opportunity to survey events in Indonesia, but he also made known his interest in them. An active backer of civic action since the Korean War, he was very influential in maintaining the US Army's connection with the Indonesian Army, through both Colonel Benson and his counterpart General Nasution.

With this background on the American players, let us look at how the Military Assistance Program to Indonesia operated.

\section{Aid to the Indonesian Army}

Before assessing the impact of US training on the Indonesian Army, it should be realized that the US government, and specifically the US Army, did not suddenly enter into an aid program with the Indonesian Army in the late 1950s.

US support to the military began with a modest assistance effort to the Mobrig in late 1948 , and to the fledgling air force in 1950.29 As early as 1952-1954, the National Security Council was making low-key expressions regarding its concern to prevent Communist influence and infiltration spreading in Indonesia and to strengthen the non-Communist elements within the Indonesian government. One of the key prerequisites to this effort, however, was that the United States had to avoid all appearance of interference in

\footnotetext{
27 Benson, conversation, February 4-5, 1988.

${ }^{28}$ Bunnell Notes, "The Kennedy Initiative in US Army-TNI Relations," pp. 3 and 20-28.

${ }^{29}$ Rudolph Mrazek, The United States and the Indonesian Military: 1945-1965 (Prague: Oriental Institue in Academia, 1978), p. 92; conversation with Professor Kahin, April 1, 1988; DDRS(79) 33A; this is a staff study from the Joint Chiefs of Staff, dated January 16, 1950, which covers the general area of China. Essentially, it notes that with the loss of China to the Communists, the best way to maintain the rest of Southeast Asia was through a program of military assistance. It further states that a good foundation for resisting communism could be laid in Indonesia and recommends the approval of $\$ 5$ million for the Indonesian constabulary (this is the original term used in the document).
} 
Indonesian affairs. ${ }^{30}$ The assistance was therefore provided largely in the form of military training for Indonesian officers, a program that very early on was seen to offer great potential for increasing US influence in Indonesia. ${ }^{31}$ This potential was further underlined in 1956, in an NSC Progress Report which pointed out that out of the thirtyfive officers trained in the US, thirty were from the Army and of those thirty, four held key positions on the General Staff (SUAD). ${ }^{32}$

As noted above, with the outbreak of rebellion in 1958, both Ambassador Jones and the US military attache tried to convince the DOD that they should support the Indonesian Army. On April 15, 1958, Ambassador Jones cabled the Department of State to urge that the US make a tangible gesture of commitment to the Indonesian Army in order to support the pro-American, anti-Communist top officer group. He specifically proposed: 1) that the US deliver on the Indonesian request for military equipment, 2) that the DOD invite the Army's top officers to the Pentagon for a discussion of that request, 3) that Indonesian officers be offered attendance at the US Army's Command and General Staff College (CGSC) and that additional training be offered for officers and NCOs, 4) and finally that parachutes be provided the Army. ${ }^{33}$

According to Colonel Benson, the failure of the PRRI/Permesta Rebellion provided a turning point for the DOD's attitude and outlook towards Indonesia. After General Nasution visited Washington in the summer of 1958, a warm relationship developed between him and General Maxwell Taylor, Chief of Staff of the Army, ${ }^{34}$ which was to bear fruit. In September 1958, the Joint Chiefs of Staff advised continuance of the Token Military Aid Program, ${ }^{35}$ which had been implemented to assist the Indonesian Army as the only non-Communist force with the capabilities to obstruct the PKI. The Chiefs argued that the Program had already achieved its limited objectives and the momentum thus generated had to be maintained. ${ }^{36}$ They further insisted that, if given encouragement in the form of aid, Nasution would carry out his plan for control of the Communists.

30DDRS(79) 46A; NSC Report, dated June 19, 1952, "Courses of Action, reference Indonesia"; DDRS(77) 196B; NSC Report (November 10, 1953), "Objectives and Courses of Action for Indonesia"; DDRS(81) 488A; NSC Report (August 4, 1954), "Policy Objectives for the Far East."

${ }^{31}$ DDRS(82) 001192; NSC Progress Report on NSC Decision 171/1 (Policies and Courses of Action in Indonesia), dated July 12,1954, concludes that the easiest way to extend US influence was through the training of Indonesian officers in US Service Schools. To lessen the financial burden on the Indonesian Armed Forces, the Department of Defense (DOD) was considering giving the Indonesians free transport on US military aircraft.

32DDRS(82) 001194, NSC Progress Report (October 10, 1956).

33Jones, Possible Dream, p. 127.

${ }^{34}$ Benson, correspondence and conversations, January 11 and February $4-5,1988$. According to Benson, they got along like two long-lost friends.

${ }^{35}$ Apparently this program was the special airlift of military equipment to Indonesia from August 15-29, 1958, as relations between the US and Indonesia began to mend after the PRRI/Permesta Rebellion. See Jones, Possible Dream, pp. 148-54. Jones states that after six months the US had succeeded in re-equipping twentyone infantry battalions, about 16,000 men. (Ibid., p. 154.)

36DDRS(82) 002386;"Memorandum for the Secretary of Defense, re: Token Military Aid Program for Indonesia (22SEP58)." The JCS also recommended the prompt completion of the original program in its entirety; the approval of an augmented program (which had becn forwarded on July 23 and 31, 1958); and the early determination of a permanent Military Assistance Program for Indonesia. 
Two underlying factors, other than the arguments of Colonel Benson and Ambassador Jones, brought the US Army to this decision to support the Indonesian Army. The most compelling of these was the burgeoning Soviet aid effort in Indonesia, which had been made all the easier by US policy during the rebellion. The US had antagonized Jakarta, for not only had it refused aid to the central government on the ostensible grounds of "neutrality," but its assistance to the rebels was regarded as responsible for the sinking of the Indonesian Navy's flagship (May 18, 1958) and the bombing of Ambon the same day. ${ }^{37}$ The first shipment of Soviet aircraft had arrived on May 6, 1958 and heralded what was to become an extensive relationship between the Indonesian Air Force and Navy`and the Soviet military. ${ }^{38}$

The second factor that contributed to the new US position was the performance of the Indonesian Army during the PRRI/Permesta Rebellion. Prior to the TNI attack on the rebels, according to Benson, the Pentagon had inquired sarcastically, how the Indonesian Army was going to cross the straits to Sumatra and land troops. The military attaché had responded that, if they had to use every ship in the archipelago and lash together rafts from logs and empty oil drums, they would make the assault. ${ }^{39}$ On the heels of the TNI's successful operations in Sumatra, the US Navy's Chief of Intelligence, Admiral Laurence Frost, made a visit to Jakarta. He agreed with Ambassador Jones's contention that the Indonesian military leadership was the key to the internal political situation and that the US must show tangible support for the Army leadership. ${ }^{40}$ In July, a report from the Naval attaché asserted that the impact of US training on the Indonesian officer corps was underestimated. It described the success of the program with the Indonesian Army and insisted that the effects of this type of effort were significant. The cable concluded that US priority objectives should be to aid the Army in order to achieve control of the Communists, help the economy, and influence political changes. 41

These efforts met with success. In January 1959, the National Security Council approved an augmentation to the Token Military Aid Program, and Washington acknowledged that the key to US efforts to curtail Communist influence in Indonesia was the Army. ${ }^{42}$ Even in 1960, as the West Irian dispute was heating up and Washington

\footnotetext{
${ }^{37}$ The link was made with the capture of Pope after the attacks.

${ }^{38}$ The Soviet Union virtually equipped both services. This aid, plus the extensive training required to operate the equipment, gave them substantial influence in those services.

${ }^{39}$ Benson, February 4-5, 1958. The Indonesians had been counting on the use of the Dutch KPM fleet; however, after the takeover of Dutch interests in the area, the flect was withdrawn. As a result, the Indonesian military had to scramble to find ships, which they finally did, buying them from Poland and the USSR (Conversation with Dr. Ben Anderson). See also, Daniel S. Lev, Transition to Guided Democracy: Indonesian Politics 1957-1959 (Ithaca: Cornell Modern Indonesia Project, 1966), p. 35. Mrazek, United States and Indonesian Military, Part 1, pp. 173-75 and Part 2, p. 20. He states that the performance of the Americantrained officers came as quite a surprise, all the more so when it was realized that it was American tactics and doctrine that had been used in executing the opcrations.

${ }^{40}$ Jones, Possible Dream, p. 147. The date of the visit was May 8, 1958.

41DDRS(82) 002387; Cable from the Naval Attaché's visit to Jakarta to CINCPAC, dated July 13, 1958. The cable is from an attaché, presumably, in the US Embassy in Australia to Major General Harris. Additional emphasis is mine.

42DDRS(84) 001980; NSC Report 5901 (January 16, 1959). This document approved the augmentation; additionally, it attributed the anti-PKI stance of the Army to US training of its officers, who now occupied responsible positions and exerted strong influence in orienting the Army to the West and the US. It
} 
rejected Nasution's request for further aid, it recognized the need to maintain some form of military assistance. ${ }^{43}$ An NSC Report, dated December 19, 1960, reasserted that the Indonesian Army's position was the principal obstacle to communism, and credited this to the training that several hundred Indonesian officers had received in US Army schools. It further recommended that the ties between the US and the Indonesian police and military be maintained and strengthened. ${ }^{44}$

Both the Indonesian government and the American Embassy in Jakarta saw the entry of the Kennedy Administration as promising new opportunities for the expansion of military aid. Ambassador Jones was quick to grasp this opportunity, and wasted no time in sending a cable to Washington suggesting a complete reassessment of United States policy and courses of action in Indonesia. ${ }^{45} \mathrm{He}$ followed this in March with a current assessment of the US military aid policy to Indonesia, and a proposal for a full scale MAP not tied to a mutual security pact. He asserted that, since the fundamental purpose in providing this aid was political, i.e., strengthening the anti-Communist leadership, the US had to recognize that decisions on equipment "must be based on Indonesia's own concepts of roles and missions, which are not confined to internal security alone." 46

These entreaties from Jakarta did not fall on deaf ears in Washington. In May 1961, Acting Assistant Secretary of Defense William P. Bundy recommended to the Special Assistant to the President, Ralph A. Dungan, that the US restart the 1957 aid program. He proposed that the largest portion of it go to the Army, and token amounts to the Air Force and Navy, so that the Army should not be perceived, too clearly, as the instrument of US policy. 47

Throughout the Kennedy years, and to a lesser extent under the Johnson Administration, the Army was to be perceived as the key to maintaining a non-Communist Indonesia, but the West Irian dispute, Konfrontasi, and finally Sukarno himself were to prove formidable obstacles to be overcome. ${ }^{48}$ It was not the US Military Assistance Pro-

recommended an expansion of US training of Indonesian officers and efforts to curtail Sino-Soviet bloc training programs.

${ }^{43}$ The US government did not want to provide substantial arms assistance to Indonesia because it could have been used against its NATO ally, the Netherlands, in West Irian. As a consequence of this decision, Nasution was forced to turn to the Soviet Union which not only supplicd the Army, but provided a very impressive package to all the services, in January 1961.

44 It went on to recommend an increase in their capabilities to maintain internal security and to combat communism, and continuing aid in the form of arms, equipment, and training on a limited basis. See DDRS(82) 000592;"NSC Report \#6023: Policy on Indonesia," December 19, 1960.

${ }^{45}$ DDRS(77) 125A; Cable from Ambassador Jones to the Secretary of State dated January 26 and 28, 1961.

${ }^{46} \mathrm{DDRS}(77)$ 125C; Cable from Jones to the Secretary of State, March 7, 1961. This is a four-page document that essentially boils down to, "if we wish to offset the huge Soviet aid program to Indonesia, we do not need to match them dollar for dollar, but only show the Indonesians that we are willing to treat them with more than token respect." Emphasis is mine, above.

47DDRS(75) 154C; memo dated May 17, 1961. After 1955, Indonesia had informed the US it did not need American assistance, then in 1957 it requested the program to restart, but since the Indonesians would not sign a mutual assistance agreement, the program was conducted as a token sales program. For example, in FY' 59 the US was to provide $\$ 21$ million in return for only $\$ 700,000$ in payment.

${ }^{48} \mathrm{DDRS}(\mathrm{RC})$ 558D; Cable from George Ball to US Representatives in Europe (January 28, 1962); he stated that the US would continue to supply arms to Indonesia in spite of the Western New Guinea question, in order to maintain influence with the Indonesian government. DDRS(82) 001786; "Memorandum from Dean Rusk to President Johnson, re: Meeting with Tunku Rahman"; Rusk told Johnson that when meeting with Tunku 
gram to Indonesia that was the cornerstone of American influence, however. Apart from the officer training in the United States, it was the US Civic Action Program that made the greatest impact on the Indonesian Army. ${ }^{49}$ Civic Action was the Kennedy Administration's new approach to the Third World, receiving prompt support from both within and outside the government. To many minds, Indonesia provided the perfect setting for a Civic Action Program.

Just prior to Sukarno's Washington visit in April 1961, 50 Brig. Gen. Edward Lansdale wrote a memorandum to the Deputy Assistant to the Secretary of Defense, stating his desire to put together a Civic Action Program (CAP) for Indonesia, to be presented to Sukarno during his US visit. Lansdale noted the benefits that this type of program could achieve, i.e., building up the Indonesian Army and bringing both it and the US Army closer to the Indonesian people. ${ }^{51}$ While this is the first mention of a CAP for Indonesia, and Sukarno was not briefed on it, the new administration in Washington was receptive to the idea. ${ }^{52}$

One of the first steps in bringing a CAP to Indonesia was taken in August 1961, when a mission headed by Professor Donald Humphrey of the Fletcher School and Dr. Walter Salant of the Brookings Institution travelled to Jakarta to assess the possibilitites for such a program in Indonesia. ${ }^{53}$ The Humphrey Mission received a thorough briefing from Nasution on the Indonesian Army's role in nation building, and on its return it issued a very positive report on conditions in Indonesia for a CAP. ${ }^{4}$

The CAP for Indonesia was launched in mid-1962, and by early 1963 it was in full swing. It would weather all the crises that were to arise between then and October 1, 1965. The importance of this program in the development of the TNI cannot be overestimated. The assistance provided by the US permitted the TNI to undertake a new mission in the villages, both securing its presence in the community and confronting the PKI. It is, then, of key importance to understand the origins of the CAP and who was responsible for overseeing it.

\section{The Civic Action Program}

The United States Civic Action Program in Indonesia never assumed the proportions of its counterparts in the Philippines or Vietnam. On the contrary, the TNI

Rahman he should stress that the military aid then going to Indonesia was for those elements that were interested and capable of resisting a PKI takeover. Emphasis is mine.

${ }^{49}$ For purposes of this article I treat the CAP as separate from the MAP, although this is not, in fact the case. Funding for a CAP is contained within MAP funds. However, since the vast majority of military assistance to Indonesia was slated for Civic Action, it is simpler to use the torm CAP instead of inter-mingling the two terms. 50 This was Sukarno's first official visit to Washington under the auspices of the Kennedy Administration.

51 DDRS(75) 154B; Memo dated April 12, 1961.

52 Bunnell Notes, pp. 1-4b and pp. 8-15; Bunnell writes that the probable reason that a proposal was not forwarded was Lansdale's lack of comprehension of the Indonesian political scene, as well as a similar lack concerning internal US government debate over Indonesian policy and the West Irian issue. These pages provide an overview of the administration's developing enthusiasm for civic action.

${ }^{53}$ This so-called Humphrey Mission was an economic survey team sent to Indonesia to assess what future aid might be provided for stabilization and development. Bunnell Notes (January 1974), p. 12.

${ }^{54}$ Ibid., pp. 16-19. 
modest US effort to a supporting role. ${ }^{55}$ However, as limited as the program was in terms of money, material, and manpower, its influence on the TNI's development came to overshadow the massive Soviet and Communist Chinese aid programs to the other services.

From the outset, it is necessary to emphasize the fact that the Indonesian Army already had its own so-called "Civic Mission," which had first been formulated by Lt. Col. Suwarto when he was in the Siliwangi Division, fighting the Darul Islam. ${ }^{56}$ This is a key point in understanding the American role in the program, for from the outset the TNI did not want US advisers or counterparts, only the necessary equipment and the training to operate and maintain that equipment. 57 However much the approach to the program in the two capitals may have differed, the goal of the program was the same, i.e., to prevent the further spread of the PKI and to maintain the pro-Western and specifically proAmerican orientation of the Indonesian Army. ${ }^{58}$

Even before the return of the Humphrey Mission from Indonesia in September 1961, and the presentation of its findings, 59 efforts were already under way within the administration to put a program into Indonesia. 60 From the embassy in Jakarta, Ambassador Jones was meanwhile protesting the slow-down of MAP deliveries, and requesting that high-priority, non-combat projects continue, especially training and technical assistance. ${ }^{61}$ The program however, did not get off the ground until July 1962, when the Department of State notified the embassy that an interagency survey team was due to arrive in Indonesia in September. 62

It should be noted that in Indonesia the CAP program was not a joint US-Indonesia governmental operation as in other countries, but rather a direct US Army-Indonesian Army effort, ${ }^{63}$ in accordance with the wishes of General Nasution. ${ }^{64}$ The relationship

${ }^{55}$ Conversation with Col. Benson, February 4-5, 1988. For a confirmation of the US role see Frederick P. Bunnell, "The Kennedy Initiative in US Army-TNI Relations."

56Ulf Sundhaussen, The Road to Power: Indonesian Military Politics 1945-1967 (Kuala Lumpur: Oxford University Press, 1982), p. 138. See also Bunnell, "Kennedy Initiative,"p. 16.

${ }^{57}$ Benson conversation, February 4-5, 1988.

${ }^{58}$ DDRS (Retrospective Collection) 562F, "Mcmorandum of Conversation (President Kennedy, Ambassador Jones and Michael Forrestal)," dated October 11, 1962. Essentially, Jones points out in paragraph 8, that the CAP is of vital importance as the US is pinning its hopes on the Indonesian Army to curb the PKI. He supports this by stating that since most Army officers are US-trained, and therefore anti-Communist, the US government must maintain the program to maintain the relationship.

${ }^{59}$ Perhaps no one has unraveled the intricacies of US governmental burcaucratic infighting over this issue as well as Bunnell. His notes are the best source for demonstrating what actually was taking place

${ }^{60}$ DDRS(RC) 301A; Memorandum "CAP for Indonesia (May 17, 1962)." Harry Saunders, a member of the NSC staff, writes that Indonesia is the perfect place for a big CAP, and that this is the best way to help the Indonesian Army. Ambassador Jones had already spoken with Gen. Nasution and this could serve as the initial document to get a survey team into Indonesia.

61 DDRS(RC) 559G; Cable from Jones to Secretary of State, May 23, 1962. The reason for the slow-down of deliveries was the fact that the Indonesian government had commenced military operations in West Irian, against the Dutch, and the United States was trying very hard at the time to bring both sides to the negotiating table. (Jones, Possible Dream, pp. 188-215.)

62DDRS(RC) 560F, Cable dated July 8, 1962.

${ }^{63}$ Bunnell Notes, pp. 33-37. This was enhanced by the personal relationship between Generals Taylor and Nasution; ibid., p. 29 and DDRS(RC) 561C, Cable from the DOS to Embassy (August 31, 1962).

${ }^{64}$ Benson conversation, February 4-5, 1988. There are several reasons for Nasution's position on this issue. He had an obvious distrust of the civilian side of the US government after his experience during the 
was formalized with the selection of Col. Benson as the Special Assistant to the Ambassador for Civic Action. The Office of Special Assistant had a broad range of powers, in effect assuring that the working relationship between the US Army and the Indonesian Army leadership would be sustained, ${ }^{65}$ despite the political upheavals that affected the public conduct of US foreign relations with Indonesia.

It appears that the CAP was not, in fact, discontinued in June 1963, as Bunnell believed. 66 Not only the Americans but also the Indonesian military wanted to maintain the program, for it gave them one key tool for confronting the PKI in the rural areas; furthermore, the issue of the orientation of the officer corps was tied to the continuation of US training. ${ }^{67}$ Ambassador Jones was very sympathetic to the TNI's predicament, as was the Pentagon, where many US officers had gone to school with the senior Indonesian commanders. ${ }^{68}$ Hence, even though the Congress passed the Broomfield Amendment which halted much American assistance, selected military aid and technical training still continued throughout 1964, though at reduced levels. ${ }^{69}$ Even after Sukarno's famous August 17, 1964, Independence Day speech, the TNI was still receiving aid and equipment.

As mentioned above, the Indonesians had first developed and implemented the concept of civic action in the West Java region in order to combat the influence of Darul Islam. Under General Ibrahim Adjie, ${ }^{70}$ the Siliwangi Division launched "Operasi

PRRI/Permesta Rebellion. He was probably aware of the opposition within the Kennedy Administration to the TNI's role in the civilian sector (see Bunnell Notes, pp. 33-37)which were most strongly voiced by the Agency for International Development. In addition, he could not afford to broaden the channel for provision of aid too much, as this could increase any interference from either Sukarno or the PKI; and (this is probably one of the more important points), he feit most comfortable being able to deal with Benson.

65 Benson correspondence and conversation; Bunnell Notes, pp. 2-3 (Part II); Civic Action Briefing, given by Col. Benson, provided by the CMIP.

${ }^{66}$ Bunnell Notes; p. 4 (Part II); Benson, conversation; sce also DDRS(RC) 908C; Memo for the President from McGeorge Bundy (August 31, 1964), re: cut-off US military aid to Indonesia; Bundy recommended that the President only cut-off the training of Indonesian officers if it was no longer desired from the Indonesian side, and that all non-military training be continued. DDRS(RC) 590B; Cable from the DOS, re: cuts in aid program; this cable informed Jones of the decision of the President to support Bundy's recommendations, i.e., cuts in military training unless otherwise requested by the Indonesians and the continuation of civic action and nonmilitary training for police and internal security forces.

67 Bunnell Notes, pp. 16-19 (Part I). This is a summary of Nasution's briefing to the Humphrey Mission. DDRS(75) 118B/C (March 19/26, 1964); these are two different cables from the embassy (Jones) to the DOS, expressing how adamant Nasution was about the continuation of the US training of Indonesian officers and the CAP. The latter cable was of a personal letter from Nasution, to be sent to Robert Kennedy, Averell Harriman, and Maxwell Taylor, expressing his strong urging that these efforts be continued.

68 Most of the top Indonesian Army gencrals were graduates of CGSC. Sce Jones, Possible Dream, p. 203.

${ }^{69}$ Ibid., pp. 279, 299, and 324-25. The Broomfield Amendment, to the Foreign Aid bill passed on July 25, 1963, stipulated that all military and economic assistance to Indonesia was to be halted unless the President determined such assistance to be in the national interest. As a side note to this, the General Accounting Office conducted an inquiry into the MAP for Indonesia, publishing its findings May 6, 1964 [DDRS(79) 41A]. It found a number of technical deficiencies with the embassy's control procedures, but essentially agreed that it appeared to meet its objectives. The DOD included a dissenting opinion which is of some interest; it said that the report needed to emphasize the political nature of this MAP, to show the role the TNI-AD was assuming in government affairs and its emerging as a major force to combat communism. Therefore, Indonesia's MAP was not based on external defense, but on a policy of assisting and influencing the Armed Forces to retain a non-Communist posture.

${ }^{70}$ Ibrahim Adjie was trained in the United States and from 1960-1966 served as the Commander of the Siliwangi Division in West Java. Regarded as very capable and honest, he was also considered by Colonel 
Bhakti," after the final military defeat of Darul Islam, to reconstruct and assist in the development of the region. This program eventually became a model for the Indonesian Army in its program. ${ }^{71}$

The Indonesian Civic Action Program (Operasi Karya or Pembinaan Wilayah) focused on the dèvelopment of farming techniques and some special projects, such as transmigration and cooperative farming (in many cases these special projects were related to the major source of income for a particular region, i.e., logging or fisheries). In addition, the Army made major efforts to improve communications and roadways through all the regions under the purview of this program. ${ }^{72}$ It was also, most importantly, a national program. Prior to 1963, some regions had been conducting similar efforts autonomously, so that the launching of Operasi Karya became a way for the GHQ to regain some measure of control. ${ }^{73}$ The program's success depended to a great extent on two types of US assistance, first, money and equipment, and second, the training of Indonesian officers.

Supplying heavy engineering equipment and farm tools and providing training to support the operation and maintain the heavy equipment formed a major part of the US Army's assistance to the Indonesian Army. ${ }^{74}$ The American training of the Indonesians to operate the equipment took place in Medan, Malang, Bogor, and Jakarta. ${ }^{75}$ The construction equipment saw its heaviest use on Sumatra, where, under the auspices of the regional commander, Brigader General R.A. Kosasih, construction was begun on the huge Trans-Sumatran Highway. In addition, the US also financed the training of selected Indonesian officers at civilian institutions in the United States, in programs that related to the management of civilian enterprises. ${ }^{76}$

It is estimated that, overall, anywhere between 17 percent and 25 percent of the Indonesian Army's general officers received training in US Army service schools. Hence, it is imperative to assess the impact of this training on the development of the Indonesian Army. ${ }^{77}$

Benson as a counterinsurgency/civil affairs expert. See also, Michacl Max Ehrmann, "The Indonesian Military in the Politics of Guided Democracy, 1957-1965" (MA Thesis, Cornell University, 1967), pp. $263-64$.

${ }^{71}$ Ehrmann, "Indonesian Military," pp. 264n and 270-71.

72 Ibid., pp. 270-88. Ehrmann gives an overview of all the regional commands, but concentrates chiefly on Java.

73Ibid., p. 290.

${ }^{74}$ Civic Action Briefing by Colonel Benson. From CMIP.

${ }^{75}$ This training was conducted by a Mobile Training Team (MTT) of US Army engineers. They were responsible for training the operators and mechanics for the construction equipment.

${ }^{76}$ For example, officers were either sent to academic institutions, e.g., Harvard, for an advanced degree, or were in a group program that centered around a short course at either Syracuse or Pittsburgh. (Civic Action Briefing/Benson) For example, according to Coloncl Benson, Sudarto and Hartawan, who were the Chief and Deputy of the Engineer Corps, were trained in the US at the Engineer School (Fort Belvoir, VA), as was his contact on the Operations staff, Josef Muskita, who had been trained at CGSC. Benson correspondence, January 11, 1988.

77 The calculations are my own, drawn from the CMIP's "Current Military Data" files and The Indonesian Military Leaders: Biographical and Other Background Data (1979). 


\section{Educational Development and Training}

The impact of US Army influence on the educational system in the Indonesian Army is rather difficult to assess without attending some of the courses taught at the two armies' various training centers. However, some conclusions can be drawn from information provided by various participants during that period.

The modernization of the Indonesian Army was essentially the effort of the new $K S A D$, General Achmad Yani. General Yani had commanded troops from the company to the battalion level and above, he was well respected by his soldiers, and was professionally well-educated. ${ }^{78}$

Upon his return from Leavenworth (CGSC) in 1956, Yani was assigned to head SUAD II, as Operations Officer for the General Staff. From this position he began his reform of the Indonesian Army's educational system. It was not, however, until after he was made the KSAD, in 1962, that he began an all-out effort to modernize the Indonesian Army. Yani's efforts at modernization can be seen most readily in the educational system of the Army, but he also had a significant impact on the development of the mobile-strike forces that were the offensive component of Nasution's, and the Army's, Territorial Doctrine ${ }^{79}$ through his support of the Kostrad (Army Strategic Command). ${ }^{80}$ Like Nasution, Yani understood that the Army needed to get into the villages to compete with the Communists, and he made great efforts to get the aid and equipment necessary to accomplish this mission. ${ }^{81}$ One of Gen. Yani's major goals in his efforts at modernization was to revamp the educational system of the TNI, and the keys to this reorganization were to be the returnees from the US Army's branch schools. Generally speaking, an officer returning from a tour in a US Service School would be assigned as an instructor in the corresponding TNI Training Center for at least one year. 82

But Yani was no less deeply concerned with the long-term professional development of the senior officers. He established what was known as the "C" Course at SSKAD (Sekolah Staf dan Komando Angkatan Darat: Staff and Command School). This was a special, short, one-time course for the most senior officers in the TNI who, because of their Revolutionary experience, had not followed the normal pattern of development

\footnotetext{
${ }^{78}$ Ibid. According to Colonel Benson, Yani was ideal for the position of KSAD; he looked the part, he was physically fit, his appearance in uniform was immaculate, he was professionally competent, and he was politically astute.

${ }^{79}$ Mrazek, United States and Indonesian Military, pp. 50-53 (Part II). Mrazek gives the impression that Nasution and Yani were widely divergent on this issue. Benson in conversation with me gave the impression that the development of mobile-strike forces did not go unnoticed and was not unfavorably received by the Pentagon.

${ }^{80}$ Benson, correspondence, January 11, 1988. The Kostrad is the descendant of the Army General Reserve (Caduad) which was formed in 1961 from the Irian Battle Command. McVey, "Post-Revolutionary Transformation," Part 2, p. 176.

${ }^{81}$ DDRS(RC) 562D; Cable from Embassy, September 14, 1962, re: "Conversation between Yani and Benson reference CAP." According to Benson, Yani stated that Nasution did not understand the program; Yani wanted to train key officers in civil affairs and economic development at the University of Pittsburg. Benson continued, that Yani believed that the Army could carry the villagers if it showed it could produce results, not promises like the PKI. Benson concluded that Yani's concept was "right out of the book." This is not to imply that the Army was not in the villages after 1963. Rather, with the lifting of martial law in 1963, the Army no longer had any explicit tasks there, while the civilians were making major efforts to regain their lost positions.

${ }^{82}$ Benson, correspondence, January 11, 1988.
} 
for Army officers. This special course taught them the new staff techniques, as well as the new operational developments that had been learned in the United States. ${ }^{83}$

Perhaps Yani's most notable impact on the educational system, was in the creation of the Military Academy at Magelang, modeled on the US Military Academy at West Point, New York. Colonel Benson relates that he passed to the Indonesian Army all the available information on the US Academy's courses, structure, curriculum, and organization, so the Magelang Academy became, on a smaller scale, almost a duplicate for West Point. ${ }^{84}$

Many other courses contributed to the development of the Indonesian Army, but it is very difficult to pin-point the precise effect of some of them. ${ }^{85}$ In addition, these courses, while certainly having an influence on the Indonesian Army, were apparently not conducted on a continuing basis. ${ }^{86}$

Of the regular courses conducted at US Army training centers, which were attended by the Indonesians, the most potent and influential was the year-long course at the Command and General Staff College (CGSC). This course is designed to prepare the US Army's middle-ranking officers for command and staff level positions in divisional units or higher. The course content varies, but, generally speaking, the majority of the course load for the years 1954-1964, concentrated on operations (see Tables 1 and 2). ${ }^{87}$ Yani's efforts at modernizing the fighting units of the Indonesian Army would have benefited greatly from this emphasis in the curriculum. 88

The US training received at CGSC also served another important function from the point-of-view of the Indonesian Army leadership, that of securing the loyalty of the officer corps. ${ }^{89}$ Here, attendance would not be sufficient to secure such loyalty, for an individual officer would have to feel that on his return he had received an assignment commensurate with the high prestige school. As can be seen from the Appendix, the initial group of officers trained at the CGSC were mainly infantry officers, and their fol-

83 Ibid.

${ }^{84}$ Ibid. Peter Britton, "The Indonesian Army: Stabiliser and Dynamiser," in Showcase State, ed. Rex Mortimer (Sydney: Agnus and Robertson, 1973), pp. 97-98; Britton points out that the Magelang cadets received intense indoctrination in the concept of Dwi-Fungsi, something obviously absent from West Point's curriculum.

${ }^{85}$ There was a special course run in Hawaii (1959) on counter-insurgency/intelligence operations, where a great deal of political information was taught that apparently was very influential on theArmy's development. Additionally, there were other courses, but the course content is not available. ibid. DDRS(75) 173B; Memo for McGeorge Bundy from M.V. Forrestal (February 6, 1964), re: Aid to Indonesia. Forrestal states that DOD has all its training programs for Indonesian officers under review, had cancelled $\mathrm{Ft}$. Bragg/Counter-Insurgency courses, but that there were some courses that were going or starting soon that, "would make British hair stand on end."

${ }^{86}$ Benson, January 11, 1988; he mentioned that the Hawaii course was set-up on the request of the Embassy and was for Indonesians only.

${ }^{87}$ R. A. Doughty and K. V. Smith, The Command and General Staff College in Transition, 1946-1976 (Staff Study for the Command and General Staff College, 1976).

88 According to Benson, Yani told all the officers preparing to attend CGSC to pay attention to the sections on Operations and Intelligence, but that they need not overly concern themselves with Logistics and Administration. Benson, Interview January 11, 1988.

${ }^{89}$ McVey, "Post-Revolutionary Transformation," Part 2, pp. 162-71. While the United States was not the only country to provide military training, it was, and still is, considered the most prestigious of the foreign training assignments. 
low-on assignments were, to a great extent, made with an eye towards securing their loyalty.

Table 1. Content of Curriculum at the US Command and General Staff College According to Staff Areas ${ }^{90}$

(Figures are Percentages)

$\begin{array}{ccccccc}\text { Year } & \text { Ops } & \text { Intell } & \text { Log } & \text { Pers } & \text { Other } & \text { Total } \\ 1954 & 53.8 & ? & ? & ? & ? & 100 \\ 1956 & 54.3 & 12.6 & 24.5 & 6.8 & 1.8 & 100 \\ 1958 & 48.6 & 15.8 & 22.2 & 10.7 & 2.7 & 100 \\ 1959 & 41.7 & 17.0 & 25.6 & 10.8 & 4.9 & 100 \\ 1960 & 40.0 & 18.0 & 26.0 & 11.0 & 5.0 & 100 \\ 1961 & 40.0 & 18.0 & 26.0 & 11.0 & 5.0 & 100 \\ 1963 & 44.1 & 13.1 & 20.4 & 8.8 & 13.6 & 100 \\ 1966 & 42.0 & 11.0 & 16.0 & 6.0 & 25.0 & 100\end{array}$

Table 2. Hours of Instruction in Tactical Operations at the US Command and General Staff College ${ }^{91}$

$\begin{array}{ccccc}\text { Year } & \text { Division } & \text { Corps } & \text { Army } & \text { Total }^{92} \\ 1953-1954 & 364 & 119 & 119 & 602 \\ 1954-1955 & 378 & 153 & 86 & 617 \\ 1955-1956 & 349 & 183 & 88 & 620 \\ 1956-1957 & 309 & 210 & 66 & 585 \\ 1957-1958 & 403 & 75 & 45 & 523 \\ 1958-1959 & 398 & 63 & 48 & 509 \\ 1959-1960 & 351 & 78 & 42 & 471 \\ 1960-1961 & 372 & 75 & 42 & 489 \\ 1961-1962 & 366 & 69 & 30 & 465 \\ 1962-1963 & 312 & 54 & 30 & 396 \\ 1963-1964 & 303 & 66 & 33 & 402 \\ 1964-1965 & 288 & 66 & 39 & 393\end{array}$

Relevant to all this was a CIA report of October 1966, where the Agency stated that approximately 2,800 Indonesian officers had been trained in US Service Schools, and that the impact of US/Western training was extensive. US military manuals and texts were being widely used, and POIs (Programs of Instruction) in Indonesian Army branch schools were nearly identical with their US counterparts. In spite of the Indonesian gov-

\footnotetext{
90Doughty and Smith, Command and General Staff College. The terminology is as follows: Ops/Operations, Intell/Intelligence, Log/Logistics, Pers/Personnel. These are the four major positions on any staff and instruction in their respective functions is concerned with managing the information flow to each for each staff officer and the unit's resources that are dedicated to that office, in a war-time environment, so that the commander has timely and accurate information on which to base his decisions.

${ }^{91}$ This data has been extracted from ibid.

${ }^{92}$ Divisional operations concerns the deployment of battalions/brigades, Corps operations is concerned with the deployment of divisions, and Army operations is concerned with the deployment of corps/divisions.
} 
ernment's anti-American posture, US training and equipment was still highly valued by Indonesian military officers. ${ }^{93}$

It is noteworthy, too, that from 1958, when a large number of Indonesian officers began to receive training in the US Army's CGSC (see Table 3 and Appendix) the number of course hoùrs allocated there to airborne and special operations saw a major increase. This may have had an effect on the increased attention subsequently paid by the TNI to such operations.

\section{The Special Forces (Komando Pasukan Khusus: Kopassus)}

The RPKAD (Resimen Parakomando Angkatan Darat, Army Parachute Regiment) was originally formed on April 16, 1953. It is a descendent of the Third Territorial Commando Force, formed by Alex Kawilarang in West Java in 1952. The first commander of this unit was Major Idjon Djambi, a former KNIL (Koninklijk Nederlandsch Indisch Leger, Royal Netherlands Indies Army) officer. ${ }^{94}$ The RPKAD appears to have been a product of its time, when elite units, usually airborne, were one of the symbols of a nation's status. ${ }^{95}$ But although the RPKAD was in existence before Gen.Yani became an influential figure in the Indonesian Army, Benson credits Yani with turning the RPKAD into the kind of mobile force the government, especially the Army, needed to impose its will throughout the archipelago. 96

The RPKAD only became nationally prominent as a result of its operations during the PRRI/Permesta Rebellion, which led to its deployment, along with other elite units, in the operations against the Dutch in West Irian in 1961-1962.97 The operations in West Irian proved to be the unifying factor for these elite Army units, which were grouped under one command, Tjaduad (Army General Reserve). ${ }^{98}$ The operations in West Irian

93DDRS(79) 343B; CIA Report "Communist Military Assistance to Indonesia," October 1966.

94 McVey, "Post-Revolutionary Development," Part 2, p. 174 gives the date for the formation of the Third Territorial Komando Force; Dr. Ben Anderson supplied me with the information about Djambi. If anyone could be said to have molded the RPKAD, it was perhaps its most influential commander, Sarwo Edhie, who was a graduate of the US Army's Infantry School at Ft.Benning, Gcorgia, where the US Army's Ranger course and Airborne course are located. This is not to say that what he learned there influenced the tactical deployment of the RPKAD above company-level, but it would have given him a very sound basis for developing training programs for his officers and NCOs. (Current Military Data.)

95 Benson, correspondence and conversation, January 11, and February 4-5, 1988. This is probably at least a partially correct assessment; according to Lt. Col. Jusuf Domi (Army Attaché, Indonesian Embassy), however, the need for a force of this nature was recognized during the insurrection in East Indonesia (1952, the Republic of South Moluccas). He said that General Poniman, who was present during the Republican forces' attack, related to him that the staff realized then that their losses would have been much lighter had a more highly mobile force been available.

96 Benson, correspondence with the author, January 11, 1988.

97 McVey, "Post-Revolutionary Development," Part 2, p. 174; the other units were the Raider Battalions from the Java divisions (Green Berets) and an Airborne unit, Brigade III, that was part of this system; apparently it was trained in airborne operations only, which distinguished it from the RPKAD. Additionally, the Navy had the KKo (Commando Corps) and the Air Force had its PGT (Pasukan Gerak Tjepat). Of all these units the Army's held the most influence, closely followed by the KKo.

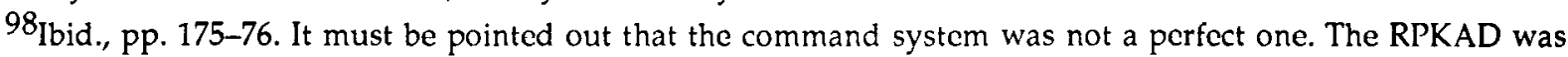
more directly linked to the center than the other elite Army units, which kept some tics with their regional divisions. These ties were even stronger in the case of the Navy's and the Air Force's units, which only responded to their respective services. 
were conducted under the control of the Mandala Command (January 1962), led by Major General Suharto and comprised mostly of Tjaduad units. This experience quickly formed the basis for a shared sense of camaraderie amongst the Army's elite units. Combined with the political fervor surrounding the campaign and the prestige accumulated by Suharto as their commander, this spirit helped establish Tjaduad as a force on which the center-and particularly Suharto-could rely. ${ }^{99}$ Following the conclusion of the West Irian operations, the Tjaduad was reorganized as the Kostrad (Army Strategic Command) in May 1963,100 as part of the efforts of the "para-minded" Army leaders to create an Airborne division for Indonesia. ${ }^{101}$

The main mission of the RPKAD has been to function as a Quick Reaction Force to any threats throughout the Indonesian archipelago. In order to be able to react as swiftly as possible, its command structure has as few levels as possible. Both before and after October 1, 1965, the RPKAD chain-of-command has run directly to the Army Chief of Staff. ${ }^{102}$ It is also not unreasonable to speculate, based on its deployment during the immediate aftermath of the October 1, 1965 Affair alone, that the RPKAD has acquired an additional mission in the field of intelligence. Most likely it is associated with the Intelligence Task Force of the Badan Intelijen Strategis (BAIS or Strategic Intelligence Unit). ${ }^{103}$

\section{Territorial Warfare Doctrine}

Even though the Indonesian Army's Territorial Warfare Doctrine pre-dated US influence, the doctrine was significantly reinforced in its development by the American Military Assistance Program. This assistance made it possible for the TNI to return to the villages, a function that had been denied them after Sukarno lifted martial law in May 1963. In order to confront the spread of PKI influence in the villages, the Army needed to implement the strategy that had worked so well for it in West Java. It lacked, however, the funds and equipment to conduct this operation, and it was this assistance the US was able to provide it. In the process, the Indonesian Army was able to translate its doctrine for territorial war into a governing ideology, which soon came to be known as DwiFungsi, or dual function. 104

The concept of the Army's dual function grew out of Nasution's "Middle Way" doctrine of the 1950s, according to which the Army would neither seek to overthrow the government nor remain politically inactive. The concept was formalized at the Army seminar held in April 1965, where it was declared that the armed forces had a dual role as both a "military force" and a "social-political force." As a "social-political force" its activities included participation in "the ideological, political, social, economic, cultural and religious fields." 105

\footnotetext{
99 Ibid., p. 176 and footnote.

100 Ibid., p. 177.

${ }^{101}$ Ibid. McVey also points out that this was finally achieved in Junc 1966 with the formation of the LINUD (Airborne division).

${ }^{102}$ Conversation with Colonel Benson, February 4-5, 1988; and with Colonel Harold Maynard, March 17, 1988.

${ }^{103}$ BAIS is equivalent to the Defense Intelligence Agency.

${ }^{104}$ Crouch, Army and Politics, p. 345. The doctrine was called Dwi-Fungsi after the all-Army seminar in August 1966 which endorsed the all-pervasive expansion of the armed forces into Indonesian life.

${ }^{105}$ Crouch, Army and Politics, pp. 24-25. Sec also, Sundhausscn, Road to Power, pp. 126-27.
} 
Table 3. The Number of Hours of Instruction in Airborne Operations Given at the Command and General Staff College (1953-1965)

Class

1953-1954

$1954-1955$

1955-1956

1956-1957

$1957-1958$

1958-1959

1959-1960

1960-1961

1961-1962

1962-1963

1963-1964

1964-1965
Title

Airborne Operations

Airborne Operations

Airborne Operations

Airborne Division Operations Special Operations

Airborne Operations, Army Aviation and

Unconventional Warfare

Airborne Operations, Army Aviation and

Unconventional Warfare Course of Study 108

Airborne Operations, Army Aviation and

Unconventional Warfare Course of Study

Airborne Operations, Army Aviation and

Unconventional Warfare Course of Study

Department of Airborne Operations

Department of Joint, Combined and Special Operations

Department of Joint, Combined and Special Operations

Department of Joint, Combined and Special Operations
Hours of Instruction

61

60

29

65

$148^{107}$

159

165

164

136

171

166

169

The institutionalization of the doctrine was accomplished through the establishment of the SUAD VI (Seksi Khusus Urusan Karya/Special Section for Business Affairs) which managed all the Army's extra-military affairs and officers. In addition, as already mentioned, the Civic Action Program (Operasi Bhakti) developed by the Siliwangi Division was formalized for all the Army, and was disseminated through a centralized Territorial Training School. ${ }^{109}$ The importance assigned to the Army's "dual function" is further reflected in the curriculum of Seskoad, where the doctrine receives over 32 percent of instruction time, and purely military subjects are taught less than 50 percent of the time. ${ }^{110}$ If one accepts the proposition that Seskoad is the single most important source of

\footnotetext{
${ }^{106}$ This material has been compiled by the author from the Programs of Instruction issued by the Command and General Staff College for each academic year.

${ }^{107}$ Probably, the increase in the hours of instruction was due to the growing interest within the US Army about air mobility, i.e., the use of helicopters. This came about in large measure due to the French success with them in Indochina.

108 This course of study includes operations in the areas of airborne division, airborne corps, Army aviation, air-landed operations of the infantry division, acrial resupply and unconventional warfare. ... These subject areas are grouped into one course of study presented by one department to insure the coordinated, energetic pursuit of concepts of airmobility under all conditions of warfare. ... Instruction in unconventional warfare encompasses guerrilla and antiguerrilla operations and the politico-psychological aspects of modern war within the scope of the College mission, and emphasizes the vital importance of this dimension of war, present and future." Catalog of Courses, 1959-1960. Command and Gencral Staff College.

${ }^{109}$ Sundhaussen, Road to Power, pp. 175-76. This was also confirmed by Colonel Benson who visited the training center during his second tour.

110 Charles Donald McFetridge, "SESKOAD-Training the Elite," Indonesia 36 (October 1983): 94. McFetridge attended SESKOAD 1982-1983.
} 
leaders in Indonesia, then this is the final step in the institutionalization of the Dual Function of the Army.111

\section{Conclusion}

In the course of this study it has become evident that the United States Army has had a clear impact on the development of the Indonesian Army. In the previous section, the effects of this influence were seen on the Indonesian Army's officer corps. By 1965 a common bond had come to link the officer corps of the two countries, namely US military training. Fifty-three Indonesian officers attended the US Army's Command and General Staff College in 1953-1965, most of them in the period between 1959 and 1965. In addition, almost 2,800 officers were trained throughout the US over the entire time period (see Table 4, "Number of Indonesian Officers Trained in the United States"), a figure that almost doubled between 1965 and 1976, when 5,003 students received American training. Since then, an average of 180 students a year has been trained in the United States, for a total of 6,754 students trained by 1986.112

Table 4. Number of Indonesian Officers Trained in the United States ${ }^{113}$

$\begin{array}{cc}\text { Fiscal Year } & \text { Students Trained } \\ 1950 & 0 \\ 1951 & 0 \\ 1952 & 8 \\ 1953 & 16 \\ 1954 & 15 \\ 1955 & 0 \\ 1956 & 0 \\ 1957 & 0 \\ 1958 & 0 \\ 1959 & 41 \\ 1960 & 201 \\ 1961 & 498 \\ 1962 & 1017 \\ 1963 & 568 \\ 1964 & 313 \\ 1965 & 3\end{array}$

As can be seen from Table 1 ("Content of Curriculum According to Staff Areas"), the doctrine of the TNI has not been strongly influenced by this US training. US assistance has, however, both enhanced technical skills and influenced the political orientation of the Indonesian officer corps. It is US Army training that has been primarily responsible for the orientation of the Indonesian officer corps developing in a pro-American/

\footnotetext{
111 Ibid., pp. 87-88. McFetridge also argues that Magelang may soon overshadow SESKOAD (which it apparently has) in importance, but that still does not dispute the fact that graduates of SESKOAD occupy major positions in the government.

112 Department of Defense, Security Assistance Agency, Foreign Military Sales, Foreign Military Construction Sales and Military Assistance Facts, September 30, 1986.

${ }^{113}$ Data courtesy of the Defense Security Assistance Agency.
} 
Western direction. It is also important to note, that the greatest numbers of Indonesian officers trained occurred at the height of the TNI's own efforts at Civic Action, which were supported both materially and educationally by the US. The success of this Civic Action program, in effect, hinged on the US-trained officers. The current pro-American stance of the Indonesian government can be attributed in great measure to the efforts of the United States in the 1950s and early 1960s to assist the Indonesian Army in its confrontation with the PKI. Recent history suggests that, through the still continuing education of Indonesian officers in US Army schools, this stance is likely to be maintained for some time to come. 


\section{Appendix \\ Indonesian Graduates of the US Command and General Staff College and Follow-on Assignments 114}

Rachmat Kartakusumah (1953); Chief of Staff (KAS) to the Director General of the Ministry of Defense; Deputy Chief of Staff of the General Staff of the Sumatran Command.

Achmad Y. Mokoginta (1954); Assistant Commander Siliwangi Division; Commandant SESKOAD

Candra Hasan (1955); served as SUAD I (Intelligence) until 1956, when he was fired. Did not surface again until the 1980s.

Achmad Yani (1956); Commander "Operation 17 August" (against the PRRI); SUAD II (Operations) and Commander of the Army.

Wiloyo Puspoyudo (1957); Deputy Commandant SESKOAD, member DPRGR for ABRI.

Winfried Nainggolan (1957); joined the PRRI, committed suicide.

Achmad Tirtosudiro (1957); Commander Bandung Garrison (Siliwangi), Army Quartermaster (Director Intendans AD)

Soerono Reksodimedjo (1958); Vice Governor Military Academy (AMN), KasKodam VII/Diponegoro.

Harsono Kasmowidjojo (1959); unknown.

Josef Muskita (1959); Deputy SUAD II, KAS KOANDA/Sumatra.

Sunggoro Notohamidjojo (1959); Kas Operasi Tumpas (against Andi Selle), Kas Indonesia Timor.

Suwarto (1959); Assistant Commandant SESKOAD.

Darjatmo (1959); Director Signal Corps, Kas Telekomunikasi KOTI, Panglima Bukit Barisan.

Sentot Iskandardinata (1959); Governor AMN, military attaché to Australia, Director Directorate of Transportation (AD).

Brotosewojo (1960); First Assistant Minister for Veteran's Affairs, Director Directorate of Distribution.

Abdul Rasjid (1960); also attended Engineer Course (1953), Ambassador to Cambodia/Laos and to the Philippines, Chief of the private staff (SPRI) to the Army Commander (PANGAD).

Achmad Wiranatakusumah (1960); Kas Mandala Command, Chief Group I (Intel) KOTI.

Rukmito Hendraningrat (1960); Chairman Retooling Committee[?], Chief Advance Party for Indonesian Congo Force[?], Ambassador to Pakistan.

Sutopo Juwono (1960); Instructor SESKOAD; Kas South Kalimantan.

${ }^{114}$ The list of graduates was made available to me through the office of the Deputy Commandant. The follow on assignments were obtained through the Current Military Data files and The Indonesian Military Leaders. The year an Officer graduated from CGSC follows his name in brackets, followed by his known assignment at the time. 
Alibasah Saleh (1961); unknown.

Sudradjat (1961); SESKOAD, Vice Chairman Supreme Audit Council; Secretary General Minister of Finance.

A. Muhdar Amin.(1961); Assistant Operations to the SUAD; Lecturer SESKOAD; Director Doctrine Development (HANKAM).

R. Hartojo Martodihardjo (1961); unknown.

Jonosewojo Handajaningrat (1961); Chairman Pelti (Indonesian Lawn Tennis Association).

R. Sucipto Danusukumo (1962); Commander MOBRIG, Panglima Police.

Teuku Hamzah Bendahara (1962); military attaché to Washington.

Iskandar Ranuwihardjo (1962); Kas Kodam III/Central Sumatra, military attaché to Cairo.

R. Hadi Purnomo (1962); Assistant I to the Director Military Police (CPM), Lecturer LEMHANNAS, KAS KOSTRAD.

Alamsjah [Ratu Prawiranegara] (1962); KAS regional Command South Sumatra; SUAD VII (Finance); Coordinator SPRI.

Suwito Harjoko (1962); Panglima Kodam III/Central Sumatra.

Mohamad Charis Suhud (1962); SUAD I (Intelligence); Assistant Intelligence HANKAM.

R. W. Widagdo (1962); Assistant Director Directorate of Transportation (AD).

Daniel [Daan] Anwar (1963); MOBRIG.

Subroto Kusmardjo (1963); Staff Supreme Command Economic Operations (KOTOE); Special Assistant Minister of Agriculture.

Panoedjoe (1963); Panglima KODAM III, Army Quartermaster.

Raden A. Tanuamidjaja (1963); unknown.

Barkah Tirtadidjaja (1963); Siliwangi?, Commander Karya AD.

Amino Gondohutomo (1963); GOLKAR [CDM, General Chairman Indonesian Doctors Assoc.].

Achmad Sajid Soebagio (1963); Assistant Commander SATGAS GAB "Sumpit."

Utomo Utojo (1963); Chief Army Transportation, Assistant Minister for National Business Affairs.

Widodo (1963); Assistant 4 Kas Kodam VII/Diponegoro, Assistant Kas Kodam VII/Diponegoro, Kas Kodam VII/Diponegoro.

Kartidjo [Sastrodinoto, R.] (1963); Pangdam XVII Irbar/Cendramasih; VIII (Brawijaya); Commander Army Training Center (KOPLAT-AD).

Johannus Sugito (1963); probably commander CPM in Jakarta.

Abdoellah (1964); unknown.

Augustinus Soetardhio (1964); Assistant Director CPM, Attorney General.

Sumantri Sumantoro (1964); Chief of Information SESKOAD. 
Haeruddin Tasning (1964); KAS KODAM XIV (South/Southeast Sulawesi).

Donald I. Pandjaitan (1964); SUAD IV (Logistics), killed in Gestapu.

Junus Samosir (1964); Assistant SUAD I (Intel)/Pangad.

Soedirgo (1964); Director CPM, SUAD I/Pangad.

Taswin Natadiningrat (1964); with Yani to Pakistan, Personal Staff President Suharto (SPRI); Ambassador to the Netherlands.

Mohammad Ishak Djuarsa (1964); Commander KODAM I (Aceh), Pangdam IV/Sriwijaya.

Widjojo Soejono (1964); Commander Bde III RPKAD (Airborne), PangKOPUR IV/KOSTRAD, Commander RPKAD.

Raksoseivito Sahirman (1965); involved in Gestapu.

Iman Zakaria (1965); unknown. 